\title{
PENGARUH KECERDASAN ADVERSITAS, PENDIDIKAN KEWIRAUSAHAAN DALAM KELUARGA, DUKUNGAN KELUARGA, DAN EFIKASI DIRI PADA INTENSI BERWIRAUSAHA SISWA SMK NEGERI 2 NGANJUK
}

\author{
Ayis Crusma Fradani, Pasca Sarjana Unesa \\ Cruz.Ayiz@gmail.com
}

\begin{abstract}
ABSTRAK
Penelitian ini bertujan untuk mengetahui pengaruh kecerdasan adversitas, pendidikan kewirausahaan dalam keluarga, dukungan keluarga, dan efikasi diri pada intensi berwirausaha siswa SMK Negeri 2 Nganjuk. Teknik pengambilan sampel dengan proportionate stratified random sampling, jumlah sampel 194. Hasil uji hipotisis secara parsial diperoleh kecerdasan adversitas, pendidikan kewirausahaan dalam keluarga, dukungan keluarga, dan efikasi diri berpengaruh signifikan pada intensi berwirausaha pada siswa SMK Negeri 2 Nganjuk. Hasil Uji hipotesis secara simultan diperoleh kecerdasan adversitas, pendidikan kewirausahaan dalam keluarga, dukungan keluarga, dan efikasi diri secara bersama-sama berpengaruh signifikan pada intensi berwirausaha siswa SMK Negeri 2 Nganjuk.
\end{abstract}

Kata Kunci: kecerdasan adversitas, pendidikan kewirausahaan dalam keluarga, dukungan keluarga, efikasi, intensi berwirausaha

\section{ABSTRACT}

This research is aimed to find out the effect of intelligence adversity, entrepreneurship education in the family, family support, and self-effication on entrepreneurship intention of the 2nd Vocational High School of Nganjuk. The sampling technique used is proportionate stratified random sampling, 194 respondents. The result with partial analysis showed that the adversity intellintelligence, entrepreneurship education in the family, family support, and self effication on entrepreneurship intention are significantly affect. The result with simultaneous analysis showed that intelligence adversity, entrepreneurship education in the family, family support and self-effication on entrepreneurship intention are significantly affect.

Keywords: intelligence adversity, entrepreneurship education in the family, family support, self-effication, entrepreneurship intention

\section{PENDAHULUAN}

Siswa SMK dirancang untuk belajar di sekolah dan belajar di dunia kerja dengan praktek secara nyata sesuai bidang yang dipelajari melalui program Pendidikan Sistem Ganda (PSG). Realitanya implementasi rencana strategis Depdiknas ini belum sepenuhnya dipahami oleh pelaksana dilapangan yang akhirnya membuat para lulusan SMK tidak mempunyai semangat berwirausaha dan lebih menyukai menjadi pegawai negeri sipil atau karyawan. Wawancara yang dilakukan oleh peneliti pada beberapa siswa di SMK Negeri 2 Nganjuk menunjukkan bahwa siswa memiliki kecenderungan untuk mencari pekerjaan pada orang lain baik sebagai pegawai swasta atau menjadi PNS dari pada 
berwirausaha. Salah satu cara yang dapat digunakan untuk mengatasi pengangguran atau menekan angka pengangguran adalah dengan menciptakan lapangan pekerjaan sendiri atau berwirausaha (Suci W., 2012). Ajzen dan Fisbein (1975) menambahkan bahwa intensi merupakan determinan terdekat dengan perilaku yang dimaksud dan merupakan prediktor tunggal terbaik bagi perilaku yang akan dilakukan seseorang.

Faktor-faktor penentu intensi diperjelas dalam Theory of Planned Behavior (TPB) yang dikemukakan Ajzen (2005) yaitu tiga jenis keyakinan penting. Pertama keyakinan perilaku (Behavior of Belief) yang diasumsikan berpengaruh terhadap sikap (Attitude Toward Behavior) dan dalam penelitian ini adalah kecerdasan adversitas, kecerdasan adversitas merupakan komponen dari Attitude Toward Behavior (Veronika. A, 2013). Kedua yaitu keyakinan normatif (Normative Belief) yang diasumsikan terdapat determinan dengan norma subjektif (Subjektive Norm) dalam penelitian ini adalah lingkungan keluarga, beberapa peneliti telah mengidentifikasi berbagai faktor-faktor penentu intensi dan salah satunya adalah faktor eksternal yaitu lingkungan keluarga (Ishfaq A. et al, 2012) dalam penelitian ini lingkungan keluarga meliputi pendidikan kewirausahan di keluarga dan dukungan keluarga. Ketiga adalah keyakinan kontrol (Control Belief) yang menyediakan dasar bagi persepsi kontrol perilaku (Perceived Behavioral Control) yaitu self efficacy atau efikasi diri. Dari fenomena tersebut maka penelitian ini bertujan untuk mengetahui pengaruh kecerdasan adversitas, pendidikan kewirausahaan dalam keluarga, dukungan keluarga, dan efikasi diri pada intensi berwirausaha siswa SMK Negeri 2 Nganjuk.

Definisi wirausaha menurut beberapa ahli dalam buku Daryanto dan Aris (2013) antara lain Marzuki manyatakan entrepreneur adalah seorang yang memiliki kombinasi unsur elemen internal yang meliputi kombinasi inovasi, visi, komunikasi, optimisme, dorongan semangat dan kemampuan untuk memanfaatkan peluang usaha. Dalam hasil penelitian oleh Tony Wijaya (2007) bahwa salah satu faktor wirausaha adalah adanya keinginan dan keinginan ini oleh Fishbein dan Ajzen (1975) disebut sebagai intensi yaitu komponen dalam diri individu yang mengacu pada keinginan untuk melakukan tingkah laku tertentu.

Salah satu komponen penentu intensi berwirausaha adalah kecerdasan adversitas. Nashori (2007) berpendapat bahwa adversity quotient merupakan kemampuan seseorang dalam menggunakan kecerdasannya untuk mengarahkan, mengubah cara berfikir dan tindakannya ketika menghadapi hambatan dan kesulitan yang bisa menyengsarakan dirinya. Paul Stoltz (2007) juga menyatakan bahwa kecerdasan adversitas adalah kemampuan seseorang mengatasi dan mengubah hambatan menjadi sebuah peluang. Paul Stoltz (2007) mengemukakan bahwa kecerdasan adversitas mempunyai tiga bentuk. Pertama kecerdasan adversitas adalah suatu kerangka kerja konseptual yang baru untuk memahami dan meningkatkan semua segi kesuksesan. Kedua, kecerdasan adversitas adalah suatu ukuran untuk mengetahui respons individu terhadap kesulitan. Terakhir yaitu kecerdasan adversitas adalah serangkaian peralatan yang memiliki dasar ilmiah untuk memperbaiki respon individu terhadap kesulitan yang akan berakibat memperbaiki efektivitas pribadi dan profesional individu secara keseluruhan. Indikator yang digunakan dalam penelitian ini adalah dari Stolz (2007) adapun indikatornya sebagai berikut: 
a. $C=$ Control

Kontrol menjelaskan tentang berapa banyak kendali yang siswa rasakan terhadap sebuah peristiwa yang menimbulkan kesulitan pada dirinya. Dimensi kecerdasan adversitas ini menunjukkan bahwa siswa yang memiliki kendali tinggi akan memiliki kemampuan dalam merubah hambatan menjadi peluang yang bagus.

b. $\mathrm{O} 2$ = Origin dan Ownership

Asal usul dan pengakuan mempertanyakan dua hal yaitu siapa atau apa yang menjadi asal usul kesulitan mereka dan sejauh mana siswa tersebut mengakui akibat-akibat kesulitan itu .

c. $R=$ Reach

Jangkauan mempertanyakan sejauh manakah kesulitan akan menjangkau bagian-bagian lain dari kehidupan siswa. Hal ini berhubungan sejauh mana para siswa menjangkau peluang-peluang yang ada di depan mereka.

d. $E=$ Endurance

Daya tahan dalam hal ini mempertanyakan dua hal yang berkaitan yaitu, berapa lamakah kesulitan itu akan berlangsung dan berapa lamakah penyebab kesulitan itu akan berlangsung. Penelitian yang menyatakan adanya hubungan kecerdasan adversitas pada intensi berwirausaha antara lain Veronika. A. S (2013), dengan hasil kecerdasan adversitas berpengaruh signifikan positif terhadap keinginan intensi berwirausaha pada mahasiswa.

Selain kecerdasan adversitas lingkungan keluarga juga komponen yang penting dalam pembentukan intensi berwirausaha siswa. Wasty Soemanto (2008) menyatakan, orang tua atau keluarga merupakan peletak dasar bagi persiapan anak-anak agar dimasa yang akan datang dapat menjadi pekerja yang efektif. Dalam mendidik anak, para orang tua harus mengajarkan anaknya memotivasi diri untuk bekerja keras, diberi kesempatan untuk bertanggung jawab atas apa yang dia lakukan. Indikator yang digunakan adalah dari Wasty Soemanto (2008) adapun indikatornya sebagai berikut:

a. Adanya kesibukan dalam keluarga yang bermanfaat.

Kesibukan ini meliputi aktifitas-aktifitas dalam keluarga yang berhubungan dengan wirausaha.

b. Adanya persiapan mental berwirausaha.

Mental berwirausaha siswa bisa terbentuk melalui ajaran-ajaran yang diberikan orang tua seperti belajar tanggung jawab, kreatif,dll

c. Perlakuan serta pelayanan orang tua.

Pelayanan adalah bagaimana cara orang tua mensuport atau memfasilitasi siswa dalam hal wirausaha.

Slameto dalam kutipannya Sumarni (2006) bahwa faktor lingkungan keluarga terdiri dari bagaimana cara orang tua mendidik, seberapa banyak relasi antar anggota keluarga, suasana rumah yang harmonis, keadaan ekonomi dalam keluarga , pengertian orang tua, dan latar belakang kebudayaan. Bambang B. U, Dkk (2012) menyatakan bahwa intensi berwirausaha siswa dipengaruhi oleh peran orang tua dalam mendidik atau membimbing dan mengarahkan anaknya untuk memiliki sikap berwirausaha.

Selain mendidik anak berwirausaha keluarga juga berperan memberikan dukungan pada anak-anaknya, menurut Friedman (1998) mengemukakan dukungan keluarga adalah sikap, tindakan dan penerimaan keluarga terhadap 
keluarga. Keluarga juga berfungsi sebagai sistem pendukung bagi anggotanya dan anggota keluarga memandang bahwa orang yang bersifat mendukung, selalu siap memberikan pertolongan dengan bantuan jika diperlukan. Indikator yang digunakan adalah dari Friedman (1998) adapun indikatornya sebagai berikut:

a. Dukungan Penilaian

Siswa mempunyai orang tua yang dapat diajak bicara tentang masalah atau rencana mereka kedepan, hal ini terjadi melalui ekspresi pengaharapan positif siswa kepada orang tua berupa penyemangat, atau persetujuan terhadap ide-ide

b. Dukungan Instrumental

Dukungan ini meliputi penyediaan dukungan orang tua baik secara moril seperti pelayanan, dan material berupa bantuan nyata seperti bantuan finansial.

c. Dukungan Informasional

Jenis dukungan ini meliputi jaringan komunikasi dan tanggung jawab bersama, termasuk di dalamnya memberikan solusi dari masalah, memberikan nasehat, pengarahan, saran, atau umpan balik tentang apa yang dilakukan oleh siswa.

d. Dukungan Emosional

Dukungan emosional memberikan siswa perasaan nyaman, merasa dibantuan dalam bentuk semangat, empati, rasa percaya, perhatian sehingga siswa yang menerimanya merasa berharga dan didukung.

Xue Fa Tong, etc (2011) dalam penelitian yang dilaksanakan di Multimedia University memaparkan bahwa mahasiswa tertarik berbisnis atau menjadi pengusaha karena lingkungan keluarganya adalah lingkungan bisnis dan orang tua yang terus memotivasi anak-anaknya untuk melakukan hal yang sama dengan orang tuanya. Selain lingkungan keluarga komponen penentu intensi lainya adalah efikasi diri atau kepercayaan diri seseorang atas kemamuanya sendiri.

Menurut Bandura (1997) efikasi diri adalah penilaian tentang kemampuan seseorang untuk melaksanakan sebuah tugas dalam hal yang spesifik. Efikasi diri yakni sebuah rasa optimis mengenai kompetensi dan efektifitas dalam dirinya. Anak-anak dan orang dewasa yang memiliki perasaan yang kuat akan efikasi diri lebih pantang menyerah, tidak terlalu cemas, dan tertekan (David G, Myers, 2012). Indikator yang digunakan adalah dari Bandura (1997) adapun indikatornya sebagai berikut:

a. Tingkat (level)

Tingkatan kesulitan tugas dimana ketika siswa merasa mampu untuk melakukannya. Apabila siswa dihadapkan pada tugas-tugas yang mudah, sedang, atau bahkan meliputi tugas-tugas yang paling sulit, sesuai dengan batas kemampuan yang dirasakan untuk memenuhi tuntutan perilaku yang dibutuhkan.

b. Kekuatan (strength)

Tingkat kekuatan dari keyakinan atau pengharapan siswa mengenai kemampuannya. Pengharapan yang lemah mudah digoyahkan oleh hal-hal yang tidak sesuai dengan harapan siswa.

c. Generalisasi (generality)

Keyakinan siswa akan kemampuan terhadap kemampuan dirinya. Apakah terbatas pada suatu aktivitas dan situasi tertentu atau pada serangkaian aktivitas dan situasi yang beraneka ragam. 
Nurul. I dan Rokhima. R, (2008), menyimpulkan Efikasi diri terbukti mempengaruhi mahasiswa Indonesia dan Norwegia dalam berwirausaha. Sedangkan Caecilia Vemmy. S, (2012) efikasi diri terbukti mempengaruhi secara positif dan signifikan pada intensi berwirausaha.

Fishbein dan Ajzen (1975) menjelaskan intensi sebagai dimensi probabilitas subjektif individu dalam kaitan antara diri dan perilaku. Bandura (1986) menyatakan bahwa intensi merupakan suatu kebulatan tekad untuk melakukan aktivitas tertentu atau menghasilkan keadaan tertentu di masa depan. Intensi kewirausahaan menurut Katz dan Gartner (1988) dapat diartikan sebagai proses pencarian informasi yang dapat digunakan untuk mencapai tujuan pembentukan suatu usaha. Teori Entrepreneurial Event yang dikemukakan oleh Shapero dan Sokol sebagaimana disebutkan dalam Riyanti (2003) merupakan bentuk adaptasi teori intensi dari Fishbein dan Ajzen (1975) yang selanjutnya diaplikasikan dalam dunia wirausaha. Intensi berwirausaha terdiri dari tiga dimensi yaitu:

a. Perceived desirability

Perceived desirability merupakan bias personal seseorang yang memandang penciptaan usaha baru sebagai sesuatu yang menarik dan diinginkan. Bias ini tumbuh dari pandangan atas konsekuensi personal tentang pengalaman kewirausahaan (misalnya baik atau buruk)

b. Perceived feasibility

Dimensi ini menunjukkan derajat kepercayaan dimana seseorang memandang dirinya mempunyai kemampuan untuk mengumpulkan sumber daya-sumber daya (manusia, sosial, finansial) untuk membangun usaha baru.

c. Propensity to act

Propensity to act menunjukkan dorongan dalam diri seseorang untuk bertingkah laku dan intensitasnya sangat bervariasi bagi tiap individu. Ketika propensity to act individu rendah, intensi untuk berwirausaha mempunyai kemungkinan yang kecil untuk berkembang.

Dengan demikian, tujuan dalam penelitian ini antara lain: (a) Menganalisis pengaruh kecerdasan adversitas, pendidikan kewirausahaan dalam keluarga, dukungan keluarga, dan efikasi terhadap intensi berwirausaha siswa SMK Negeri 2 Nganjuk secara parsial; (b) Menganalisis pengaruh kecerdasan adversitas, pendidikan kewirausahaan dalam keluarga, dukungan keluarga, dan efikasi terhadap intensi berwirausaha siswa SMK Negeri 2 Nganjuk secara simultan.

\section{METODE PENELITIAN}

Pendekatan yang digunakan dalam penelitian ini adalah pendekatan kuantitatif. Penelitian kuantitatif adalah suatu metode penelitian dimana data penelitian berupa angka-angka dan analisis menggunakan statistik (Sugiyono, 2013). Variabel pada penelitian ini yaitu intensi berwirausaha (Y), serta kecerdasan adversitas $\left(\mathrm{X}_{1}\right)$, pendidikan kewirausahaan dalam keluarga $\left(\mathrm{X}_{2}\right)$, dukungan keluarga $\left(\mathrm{X}_{3}\right)$, dan efikasi diri $\left(\mathrm{X}_{4}\right)$.

Populasi dalam penelitian ini adalah siswa kelas XI SMK Negeri 2 Nganjuk tahun pelajaran 2013-2014 yaitu sebanyak 375 orang siswa. Teknik pengambilan sampel dengan proportionate stratified random sampling dan menggunakan rumus slovin sehingga di peroleh sampel sebanyak 194. 
Pengumpulan data dengan menggunakan kuesioner, wawancara, dan dokumentasi.

Kuesioner disusun berdasarkan indikator dari penelitian variabel dengan menggunakan skala likert. Teknik analisis menggunakan analisis uji statistik yaitu uji $\mathrm{t}$ dan uji $\mathrm{F}$ dengan terlebih dahulu menguji validitas dan realibilitas. Uji $\mathrm{t}$ digunakan untuk menguji signifikansi variabel kecerdasan adversitas $\left(\mathrm{X}_{1}\right)$, pendidikan kewirausahaan dalam keluarga $\left(\mathrm{X}_{2}\right)$, dukungan keluarga $\left(\mathrm{X}_{3}\right)$, dan efikasi diri $\left(\mathrm{X}_{4}\right)$ secara parsial terhadap intensi berwirausaha $(\mathrm{Y})$. Uji $\mathrm{F}$ digunakan untuk menguji signifikansi variabel kecerdasan adversitas $\left(\mathrm{X}_{1}\right)$, pendidikan kewirausahaan dalam keluarga $\left(\mathrm{X}_{2}\right)$, dukungan keluarga $\left(\mathrm{X}_{3}\right)$, dan efikasi diri $\left(\mathrm{X}_{4}\right)$ secara simultan terhadap intensi berwirausaha $(\mathrm{Y})$.

\section{HASIL PENELITIAN DAN PEMBAHASAN}

\section{Hasil Penelitian}

Dari hasil analisis nilai kritis ( $\mathrm{r}_{\text {tabel }}$ ) yang diperoleh sebesar 0,444 yaitu dengan melihat pada tabel korelasi dengan menggunakan taraf kepercayaan $95 \%$ dan pada derajat bebas $=\mathrm{n}=20$. Dari data tersebut hasil uji validitas diperoleh instrumen penelitian yang digunakan semuanya mempunyai nilai yang lebih besar atau berada diatas nilai kritis ( $\left.\mathrm{r}_{\text {tabel }}\right)$, sehingga dapat disimpulkan bahwa semua indikator pada instrumen penelitian ini valid. Nilai koefisien reliabilitas nilainya lebih dari atau diatas 0,6 maka dapat disimpulkan bahwa instrumen atau kuesioner yang digunakan untuk mengetahui pengaruh variabel Kecerdasan Adversitas $\left(\mathrm{X}_{1}\right)$, Pendidikan Kewirausahaan dalam Keluarga $\left(\mathrm{X}_{2}\right)$, Dukungan Keluarga $\left(\mathrm{X}_{3}\right)$ dan Efikasi Diri $\left(\mathrm{X}_{4}\right)$, terhadap Intensi Berwirausaha (Y) Siswa kelas XI SMK Negeri 2 Nganjuk adalah reliabel.

Model regresi yang diperoleh berdasarkan hasil analisis untuk variabel kecerdasan adversitas $\left(\mathrm{X}_{1}\right)$, pendidikan kewirausahaan dalam keluarga $\left(\mathrm{X}_{2}\right)$, dukungan keluarga $\left(\mathrm{X}_{3}\right)$ dan efikasi diri $\left(\mathrm{X}_{4}\right)$ terhadap intensi berwirausaha $(\mathrm{Y})$ siswa kelas XI SMK Negeri 2 Nganjuk tahun pelajaran 2013-2014 adalah sebagai berikut: $\mathrm{Y}=1,295+0,140 \mathrm{X}_{1}+0,086 \mathrm{X}_{2}+0,127 \mathrm{X}_{3}+0,157 \mathrm{X}_{4}$. Dari persamaan tersebut, keempat variabel bebas memiliki koefisien regresi dengan arah positif. Hal ini berarti bahwa semakin tinggi kecerdasan adversitas $\left(\mathrm{X}_{1}\right)$, pendidikan kewirausahaan dalam keluarga $\left(\mathrm{X}_{2}\right)$, dukungan keluarga $\left(\mathrm{X}_{3}\right)$ dan efikasi diri $\left(\mathrm{X}_{4}\right)$ akan meningkatkan intensi berwirausaha siswa.

Uji t yaitu pengujian sendiri-sendiri (parsial) koefisien regresi variabel penelitian yang terdiri dari kecerdasan adversitas $\left(\mathrm{X}_{1}\right)$, pendidikan kewirausahaan dalam keluarga $\left(\mathrm{X}_{2}\right)$, dukungan keluarga $\left(\mathrm{X}_{3}\right)$ dan efikasi diri $\left(\mathrm{X}_{4}\right)$ terhadap variabel intensi berwirausaha (Y) siswa kelas XI SMK Negeri 2 Nganjuk. Hasil analisis diperoleh $t_{\text {hitung }}$ dari hasil analisis regresi linier berganda untuk variabel kecerdasan adversitas $\left(\mathrm{X}_{1}\right)$ sebesar 2.253 , pendidikan kewirausahaan dalam keluarga $\left(\mathrm{X}_{2}\right)$ sebesar 2.340, dukungan keluarga $\left(\mathrm{X}_{3}\right)$ sebesar 3.340 dan efikasi diri $\left(\mathrm{X}_{4}\right)$ sebesar 3.866 dan semua nilai signifikansi lebih kecil dari taraf signfikansi 0.05, maka dapat disimpulkan secara sendirian (parsial) terbukti mempunyai pengaruh signifikan terhadap intensi berwirausaha siswa kelas XI SMK Negeri 2 Nganjuk.

Uji $\mathrm{F}$ yaitu untuk menguji keterkaitan koefisien regresi secara bersamasama antara Variabel kecerdasan adversitas $\left(\mathrm{X}_{1}\right)$, pendidikan kewirausahaan 
dalam keluarga $\left(\mathrm{X}_{2}\right)$, dukungan keluarga $\left(\mathrm{X}_{3}\right)$ dan efikasi diri $\left(\mathrm{X}_{4}\right)$ terhadap variabel intensi berwirausaha (Y) siswa kelas XI SMK Negeri 2 Nganjuk. Dari hasil analisis diperoleh $F_{\text {hitung }}$ sebesar 26,277 dengan nilai signifikansi sebesar 0.000 dimana lebih kecil dari taraf signifikansi $\alpha=0,05$, hal ini berarti kecerdasan adversitas $\left(\mathrm{X}_{1}\right)$, pendidikan kewirausahaan dalam keluarga $\left(\mathrm{X}_{2}\right)$, dukungan keluarga $\left(\mathrm{X}_{3}\right)$ dan efikasi diri $\left(\mathrm{X}_{4}\right)$ secara simultan mempunyai pengaruh yang signifikan terhadap intensi berwirausaha (Y) siswa kelas XI SMK Negeri 2 Nganjuk.

Dari hasil analisis Koefisien Korelasi (R) diperoleh koefisien korelasi antara variabel kecerdasan adversitas $\left(\mathrm{X}_{1}\right)$, pendidikan kewirausahaan dalam keluarga $\left(\mathrm{X}_{2}\right)$, dukungan keluarga $\left(\mathrm{X}_{3}\right)$ dan efikasi diri $\left(\mathrm{X}_{4}\right)$ dengan variabel intensi berwirausaha (Y) siswa kelas XI SMK Negeri 2 Nganjuk adalah sebesar 0,598 mempunyai hubungan yang sedang dan positif terhadap variabel intensi berwirausaha (Y) Siswa kelas XI SMK Negeri 2 Nganjuk. Koefisien determinasi $\left(\mathrm{R}^{2}\right)$ adalah besarnya variasi yang dapat dijelaskan oleh variabel kecerdasan adversitas $\left(\mathrm{X}_{1}\right)$, pendidikan kewirausahaan dalam keluarga $\left(\mathrm{X}_{2}\right)$, dukungan keluarga $\left(\mathrm{X}_{3}\right)$ dan efikasi diri $\left(\mathrm{X}_{4}\right)$ terhadap variabel intensi berwirausaha $(\mathrm{Y})$ siswa kelas XI SMK Negeri 2 Nganjuk, dari hasil analisis diperoleh koefisien determinasi sebesar 0,344 signifikan variasi yang dapat dijelaskan oleh variabel kecerdasan adversitas, pendidikan kewirausahaan dalam keluarga, dukungan keluarga, dan efikasi diri terhadap variabel intensi berwirausaha Siswa kelas XI SMK Negeri 2 Nganjuk adalah sebesar 34,4\%, dan variasi yang dijelaskan oleh variabel lain diluar penelitian ini adalah sebesar $65,6 \%$.

\section{Pembahasan}

1. Kecerdasan adversitas terhadap intensi berwirausaha

Berdasarkan pengujian analisis diperoleh hasil bahwa kecerdasan adversitas $\left(\mathrm{X}_{1}\right)$ terbukti mempunyai pengaruh signifikan terhadap intensi berwirausaha (Y) siswa kelas XI SMK Negeri 2 Nganjuk. Hal ini menunjukan jika seorang siswa memiliki kecerdasan adversitas yang tinggi maka intensi berwirausaha juga akan menjadi tinggi. Dengan memiliki kecerdasan adversitas seseorang dapat lebih menjadi kreatif, bertanggung jawab, mandiri, dan bekerja keras, hal-hal inilah sebagian karakteristik untuk menjadi seorang pengusaha. Apabila seseorang memiliki kecerdasan adversitas yang rendah mereka cenderung tidak memiliki sifat-sifat tersebut sehingga dapat melemahan niat seseorang untuk berwirausaha.

Hasil penelitian ini mendukung temuan penelitian Veronika Agustini. S (2013), dan Tony Wijaya (2007). Penelitian ini juga sependapat dengan Siti Zulaikha Wulandari, Dkk (2013) dalam penelitianya yang berjudul analysis the influence of adversity quotient networking and capital through the entrepreneurial intentions of Unsoud's student. Selain itu penelitian ini juga mendukung temuan dai hasil penelitian yang dilakukan Muhammad Shohib (2013). Selain itu juga mendukung teori dari Paul Stolz (2007) yang menyatakan seseorang yang memiliki kecerdasan adversitas atau kecerdasan menghadapi rintangan diduga lebih siap menjalani profesi sebagai seorang wirausahawan karena mereka memiliki kemampuan untuk membuat hambatan menjadi peluang. Selain itu penelitian ini juga mendukung pendapat Stein Kristianten, Dkk (2001) yang berpendapat individu yang 
memiliki kemampuan menghadapi rintangan akan memiliki need for achivment, locus of control, dan self efficacy yang tinggi sehingga berpotensi dalam berwirausaha.

Aspek kecerdasan adversitas terdiri dari kendali (control), asal usul pengakuan (origin dan ownership), jangkauan (reach), dan daya tahan (endurence) membuat individu terdorong dalam menghadapi masalah. Siswa yang memiliki kendali (control) yang tinggi akan berinisiatif dalam melihat dan menangkap peluang-peluang usaha yang ada. Asal usul dan pengakuan (origin dan ownership) adalah faktor yang menjadi awal dari tindakan siswa, siswa yang beranganggapan berwirausaha adalah bagian dari masalah dalam dirinya maka akan memiliki kreativitas dalam berwirausaha. Jangkauan (reach), siswa yang merasa peluang-peluang yang ada dapat dijangkaunya maka siswa tersebut akan memiliki intensi berwirausaha. Daya tahan (endurence), siswa yang beranggapan suatu peluang usaha bukanlah masalah yang menyita waktu maka siswa akan berupaya berwirausaha. Temuan dalam penelitian ini menunjukan bahwa bukan hanya pada mahasiswa saja kecerdasan adversitas ini ada pada individu tetapi juga pada siswa sma atau smk hal ini sejalan dengan hasil penelitian yang dilakukan oleh Muhamad Shohib (2013). Kecerdasan adversitas siswa SMK Negeri 2 Nganjuk ini terbentuk karena pada sekolah ini terdapat kegiatan prakerin atau PSG sehingga para siswa bisa belajar secara langsung dari para pengusaha yang sukses dan belajar mengidentifikasi peluang-peluang yang ada di sikitarnya.

2. Pendidikan kewirausahaan dalam keluarga terhadap intensi berwirausaha

Berdasarkan pengujian analisis dengan bantuan komputer diperoleh variabel pendidikan kewirausahaan dalam keluarga $\left(\mathrm{X}_{2}\right)$ terbukti mempunyai pengaruh signifikan terhadap intensi berwirausaha (Y) siswa kelas XI SMK Negeri 2 Nganjuk. Hal ini menunjukan jika seorang siswa memperoleh pendidikan kewirausahaan di dalam keluarganya tinggi maka intensi berwirausaha juga akan menjadi tinggi. Cara berfikir positif terhadap kewirausahaan harusnya dibentuk sejak usia dini agar menimbulkan niat berwirausaha dalam diri individu kelak. Peran keluarga atau orang tua sangat menentukan dalam mendidik anak untuk memiliki jiwa wirausaha antara lain dengan cara memotivasi, mengajarkan untuk kreatif, berlatih bertanggung jawab dan pantang menyerah dalam kehidupan sehari-hari. Temuan penelitian ini mendukung penelitian dari Xue Fa Tong, et all (2011), Anita Volintia.D (2013), Ceacilia V (2012), Sukanti,Dkk (2011), Bambang B. U, Dkk (2012), dan Eka. A (2012). Selain mendukung penelitian ini juga tidak mendukung hasil penelitian yang di lakukan oleh Risa Ari. A (2013), dan Adwiani. S dan Ayu. N (2012). Secara umum peran pendidikan dalam keluarga dapat menumbuhkan jiwa wirausaha siswa, pengusaha yang sukses pada umumnya dipicu oleh orang tuanya baik secara langsung maupun tidak langsung. Seperti halnya pendapat dari Sukanti,Dkk (2011) sebagian responden sukses berwirausaha karena orang tuanya sudah melibatkannya untuk menjadi wirausaha.

Dalam penelitian ini juga mendukung teori dari Riyanti (2003) dalam penelitian yang di lakukan Putu Eka. D, Dkk (2014) yang menyebutkan bahwa faktor yang mempengaruhi niat berwirausaha terdiri dari dua aspek 
yaitu aspek internal yang terdiri dari demografi (usia,pengalaman,dan pendidikan), kepribadian dan motivasi dan aspek eksternal yang meliputi lingkungan keluarga dan lingkungan bekerja. Selain itu juga sejelan dengan pendapat Wasty Soemanto (2008) bahwa pelaksanaan pendidikan kewirausahaan bukan hanya di lingkungan sekolah saja tetapi juga lingkungan masyarakat dan lingkungan keluarga. Lingkungan keluarga terutama orang tua sangat berperan sebagai pengarah dan pendidik bagi anakanaknya di masa depan, jadi secara tidak langsung orang tua dapat mempengaruhi minat terhadap pekerjaan bagi anaknya dimasa yang akan datang.

Adanya kesibukan dalam keluarga yang bermanfaat, apabila dalam kehidupan sehari-hari siswa berada di lingkungan orang-orang berwirausaha maka secara tidak langsung mereka akan mempelajari baik secara langsung atau tidak langsung dan kesibukan atau kegiatan-kegiatan seperti ini akan meningkatkan intensi berwirausaha juga. Adanya persiapan mental berwirausaha, siswa yang di rumah sering mendapatkan pengajaran tentang bersikap bertanggung jawab, berani menanggung resiko,dan berkerja keras akan memiliki intensi berwirausaha yang tinggi pula.

Perlakuan serta pelayanan orang tua dalam keluarga apabila siswa di fasilitasi, dimotivasi, dan di dorong maka siswa akan memiliki intensi berwirausaha yang tinggi. Pendidikan wirausaha dalam keluarga ini termasuk kecil yaitu koefisien regresinya hanya 8,6\% tetapi berpengaruh terhadap intensi berwirausaha. Temuan dalam penelitian ini menunjukan mayoritas pekerjaan orang tua siswa adalah sebagai petani yang menghabiskan banyak waktu di bekerja di sawah sehingga memungkinkan tidak adanya pemberian contoh dan pembiasaan dalam pembelajaran atau pengajaran berwirausaha dalam diri siswa SMK Negeri 2 Nganjuk sehingga pendidikan kewirausahaan dalam keluarga tidak terlalu mempengaruhi intensi berwirausaha siswa SMK Negeri 2 Nganjuk.

3. Dukungan keluarga terhadap intensi berwirausaha

Berdasarkan analisis diperoleh variabel dukungan keluarga $\left(\mathrm{X}_{3}\right)$ terbukti mempunyai pengaruh signifikan terhadap intensi berwirausaha (Y) Siswa kelas XI SMK Negeri 2 Nganjuk. Hal ini menunjukan jika seorang siswa memperoleh dukungan dalam keluarga yang tinggi maka intensi berwirausaha juga akan menjadi tinggi.

Penelitian ini mendukung penelitian yang di lakukan oleh Muhammad. I, et all (2009), Ishfaq Ahmed, et all (2012), Teemu K and Seppo L (2008), Zahra. A (2012), Raden L. G dan Rendra. W (2012), Edi Sarwoko (2011),dan Muhamad. A (2012). Selain mendukung penelitian ini juga tidak mendukung penelitian yang di lakukan We Li (2005) adapun penyebabnya antara lain pertama, kemungkinan ada kesalahan pada penyusunan instrumen survei, dan kedua mayoritas orang tua responden adalah orang penting dan ekonominya bagus sehingga mampu menyekolahkan anaknya keluar negeri hal ini mengakibatkan para responden beranggapan bisa mendapatkan pekerjaan yang bagus pula setelah lulus dan kembali kenagaranya sehingga tidak tertarik berwirausaha yang beresiko menurutnya. Irine. P, Wardoyo (2012) dalam penelitianya menyatakan 
dukungan keluarga tidak berpengaruh pada intensi karena responden tidak mendapat motivasi dari keluarganya dan responden lebih tertarik mencoba kerja karena jenuh degan lingkungan keluarganya yang berkecimpung di dunia wirausaha. Selain itu penelitian ini juga sesuai dengan teori yang dikemukakan Friedman (1998) yang menyatakan keluarga cenderung terlibat dalam pembuatan keputusan anak ataupun anggota keluarga lain dalam mengambil keputusan atau menentukan pekerjaan nantinya.

Komponen komponen dukungan keluarga terdiri dari dukungan penilaian, siswa yang dalam keluarganya mendapat bimbingan dalam penentuan pekerjaan yang sesuai nantinya cenderung memiliki intensi berwirausaha yang tinggi. Dukungan instrumental, siswa yang dalam keluarga difasilitasi oleh keluarganya seperti mengikuti seminar atau pameran-pameran kewirausahaan akan membuat siswa memiliki nilai intensi berwirausaha yang lebih baik. Dukungan informasional, apabila siswa dalam keseharianya sering diberi informasi-informasi tentang wirausaha akan memiliki intensi berwirausaha yang baik pula. Dukungan emosional, siswa yang didalam keluarganya sering diingatkan dan disarankan agar menjadi orang yang berhasil dan orang tua yang demokratis memberi kebebasan anaknya dalam menentukan pekerjaannya kelak juga dapat meningkatkan intensi berwirausaha pada diri siswa. Temuan yang diperoleh menunjukan bahwa para orang tua siswa kurang memberikan fasilitas-fasilitas dan dukungan material seperti pembiayaan untuk mengikuti seminar kewirausahaan, hal ini disebabkan karena orang tua lebih mendukung anaknya untuk menjadi PNS ataupun karyawan swasta dari pada menjadi wirausaha.

4. Efikasi diri terhadap intensi berwirausaha

Berdasarkan analisis didapat hasil variabel efikasi diri $\left(\mathrm{X}_{4}\right)$ terbukti mempunyai pengaruh signifikan terhadap intensi berwirausaha (Y) siswa kelas XI SMK Negeri 2 Nganjuk. Efikasi diri memeliki peranan penting dalam intensi berwirausaha, semakin tinggi kepercayaan diri siswa atas kemampuan dirinya untuk dapat berusaha maka semakin besar pula intensi berwirausahanya.

Hasil dari penelitian ini mendukung penelitian dari Anuradha Basu and Meghna. V (2007), Sarwono. N dan Arif. J. (2013), Sri Rustiyaningsih (2013),dan Endi.S (2011). Selain mendukung penelitian tersebut diatas penelitian ini juga menolak penelitian Nurul. I dan Rokhima (2008) dalam penelitianya di 3 negara yang menyatakan di salah satu negara dalam penelitianya tersebut efikasi diri tidak berpengaruh pada intensi berwirausaha.

Tiga dimensi pembentuk efikasi diri antara lain tingkat (level), kekuatan (strength), dan generalisasi (generality). Tingkat (level), pembentuk efikasi diri ini mengarah pada kemampuan mengendalikan masalah, kinerja nyata, dan tingkat pencapaian, siswa SMK Negeri 2 Nganjuk sedikit banyak telah memperoleh pengalaman dalam hal berwirausaha antara lain berasal dari teori di kelas dan praktek kewirausahan di sekolah (laboratorium kewirausahaan) atau pada saat prakerin. Pada praktek kewirausahaan ini siswa bukan hanya menawarkan ke teman-temannya tetapi juga ke guru maupun staf sekolah sehingga mereka terus berfikir dan berinovasi agar berhasil. 
Kekuatan (strength), yaitu keyakinan atau pengharapan akan kemampuanya, pengharapan yang mantap atau kuat akan mendorong naiknya efikasi diri siswa sehingga tidak mudah goyah ketika ada masalah atau tidak sejalan dengan harapanya, hal yang dilakukan para guru di SMK Negeri 2 Nganjuk untuk memantapkan antara lain dengan memberi pandanganpandangan positif bahwa siswa juga bisa menjdi wirausahawan yang berhasil hal-hal semacam ini dapat mempengaruhi persepsi diri siswa sehingga meningkatkan efikasi diri. Generalisasi (generality) adalah keyakinan atas kemampuan, para guru di SMK Negeri 2 Nganjuk selain memberi pandangan posotif tentang berwirausaha juga menginformasikan pada saat berwirausaha kita akan selalu berhadapan dengan situasi yang fluktuatif sehingga wirausahawan harus siap menghadapi resiko dan selalu berinovasi serta kreatif, siswa yang memiliki efikasi rendah akan mudah putus asa dan beranggapan bahwa dia tidak mampu melaksanakan atau menjadi wirausahawan.

Temuan penelitian ini menunjukan bahwa efikasi diri adalah prediktor paling dominan yang mempengaruhi intensi berwirausaha SMK Negeri 2 Nganjuk, hasil tersebut senada dengan hasil penelitian dari Nurul. I dan Rokhima (2008) dan Ceacilia. V (2012). Efikasi diri siswa ini salah satunya terbentuk karena adanya kegiatan-kegiatan di sekolah yang berhubungan dengan dunia wirausaha seperti adanya fasilitas kewirausahaan yang ada di SMK Negeri 2 Nganjuk seperti laboratorium penjualan yang dugunakan berlatih para siswa untuk berwirausaha.

5. Kecerdasan adversitas, pendidikan kewirausahaan dalam keluarga, dukungan keluarga dan efikasi terhadap intensi berwirausaha siswa SMK Negeri 2 Nganjuk.

Berdasarkan hasil analisis diperoleh variabel kecerdasan adversitas $\left(\mathrm{X}_{1}\right)$, pendidikan kewirausahaan dalam keluarga $\left(\mathrm{X}_{2}\right)$, dukungan keluarga $\left(\mathrm{X}_{3}\right)$ dan efikasi diri $\left(\mathrm{X}_{4}\right)$ secara bersama-sama mempunyai pengaruh yang signifikan terhadap intensi berwirausaha (Y) Siswa kelas XI SMK Negeri 2 Nganjuk. Hal ini menunjukan jika seorang siswa memiliki kecerdasan adversitas, pendidikan kewirausahaan dalam keluarga, dukungan keluarga, dan efikasi diri yang tinggi maka intensi berwirausaha juga akan menjadi tinggi.

Penelitian ini sejalan dengan penilitian yang dilakukan Anuradha Basu and Meghna Virick (2007), Sarwono. N (2013), Bambang Budi. U, Dkk (2012), yang sama-sama menyatakan pendidikan kewirausahaan dan efikasi diri secara simultan pada intensi berwirausaha. Endi. S (2011) menyatakan dukungan keluarga dan efikasi diri berpengaruh terhadp intensi berwirausaha. Penelitian ini mendukung teori TPB (Theory Of Planned Behavior) yang dikemukakan Ajzen (2005) yaitu faktor-faktor penentu intensi terdiri dari tiga jenis keyakinan penting. Pertama keyakinan perilaku (Behavior Of Belief) yang diasumsikan berpengaruh terhadap sikap (Attitude Toward Behavior) dan dalam penelitian ini adalah kecerdasan adversitas. Kedua keyakinan normatif (Normative Belief) yang diasumsikan terdapat determinan dengan norma subjektif (Subjektive Norm) dalam penelitian ini adalah lingkungan keluarga, penelitian ini lingkungan keluarga meliputi pendidikan 
kewirausahan dalam keluarga dan dukungan keluarga. Ketiga adalah keyakinan kontrol (Control Belief) yang menyediakan dasar bagi persepsi kontrol perilaku (Perceived Behavioral Control) yaitu self efficacy atau efikasi diri. Sumbangan dari variabel kecerdasan adversitas, pendidikan kewirausahaan dalam keluarga, dukungan keluarga, dan efikasi diri tersebut dalam meprediksi intensi berwirausaha memang tidak terlalu besar hal ini disebabkan masih banyaknya prediktor pembentuk intensi yang belum digunakan dalam penelitian ini untuk membentuk intensi berwirausaha pada siswa SMK Negeri 2 Nganjuk.

\section{KESIMPULAN}

1. kecerdasan adversitas berpengaruh signifikan dan positif terhadap intensi berwirausaha pada siswa kelas XI SMK Negeri 2 Nganjuk, yang berarti semakin tinggi kecerdasan adversitas semakin tinggi pula intensi berwirausaha siswa.

2. Pendidikan kewirausahaan dalam keluarga berpengaruh signifikan dan positif terhadap intensi berwirausaha siswa kelas XI SMK Negeri 2 Nganjuk, yang berarti semakin tinggi pendidikan kewirausahaan dalam keluarga semakin tinggi pula intensi berwirausaha siswa.

3. Dukungan keluarga memiliki pengaruh signifikan dan positif terhadap intensi berwirausaha siswa kelas XI SMK Negeri 2 Nganjuk, yang berarti semakin tinggi dukungan keluarga semakin tinggi pula intensi berwirausaha siswa.

4. Efikasi diri berpengaruh signifikan dan positif terhadap intensi berwirausaha siswa kelas XI SMK Negeri 2 Nganjuk, yang berarti semakin tinggi efikasi diri semakin tinggi pula intensi berwirausaha siswa.

5. Kecerdasan adversitas, pendidikan kewirausahaan dalam keluarga, dukungan keluarga, dan efikasi diri berpengaruh terhadap intensi berwirausaha siswa kelas XI SMK Negeri 2 Nganjuk, yang berarti semakin tinggi kecerdasan adversitas, pendidikan kewirausahaan dalam keluarga, dukungan keluarga, dan efikasi diri semakin tinggi pula intensi berwirausaha siswa.

\section{DAFTAR RUJUKAN}

Agustini ,Veronika. S (2013), Analisis Pengaruh Kecerdasan Adversitas, Internal Locus Of Control, Kematangan Karir Terhadap Intensi Berwirausaha pada Mahasiswa Bekerja (Studi Empiris pada Mahasiswa Kelas Karyawan Unika Widya Mandala Madiun). Jurnal ekonomi. No.01 Tahun XXXV II/ Januari 2013

Ahmed, Ishfaq, et all. (2012), Do external factors influence students entrepreneurial inclination? an evidence based approach. Entrepreneurship journal, 978-953-51-0210-6, Intech, Marc 2012.

Ajzen and Fishbein. (1975), Belief, Attitude, Intention and Behavior: An Introduction to Theory and Research, Addison-Wesley Publishing Company Inc, Menlo Park, California.

Ajzen, I. (2005). The Theory Of Planned Behaviour. Organizational behavior and human discussion processes, 50, 179-211. 
Aprilianty. Eka (2012). Pengaruh kepribadian wirausaha, pengetahuan kewirausahaan, dan lingkungan terhadap minat berwirausaha siswa smk. Jurnal pendidikan vokasi, Vol 2, Nomor 3.

Arasti, Zahra (2012). normatif institutional factors affecting entrepreneurial intention in Iranian information technologi sector. Journal of management and strategy. Vol. 3, No. 2.

Ari, Risa.A (2013). Model pengembangan sikap kewirausahaan siswa smk negeri sek-kabupaten demak. Journal of economic educatiun. JEE 2. 1.

Arif, Muhamad I. (2012). Pengaruh komunikasi interpersonal dan lingkungan keluarga terhadap intensi berwirausaha siswa smk Muhamadiyah 3 Yogyakarta. Jurnal penelitian

Bambang, Dkk. (2012), pengaruh pendidikan kewirausahaan dalam keluarga dan di sekolah terhadap minat berwirausaha dengan mediasi self efficacy siswa kelas XI. Jurnal Eonomi.

Bandura, A., 1986. The Social Foundation of Tought and Action, Englewood Cliffs, NJ: Prentice Hall.

Bandura. (1997). Self-Efficacy: The Exercise of Control. New York: W.H. Freeman and Company.

Basu, Anuradha and Meghna Virick (2007),Assessing Entrepreneurial Intentions Amongst Students: A Comparative Study. 71-86. Peer reviewed papers.

Daryanto dan Aris. D. C (2013). Kewirausahaan. Malang : Gava Media.

Eka, Putu. D. Y, I Made. N, I Ketut. D (2014). Pengaruh lingkungan keluarga terhadap berwirausaha siswa kelas XI Smk Negeri 1 Singaraja. Jurnal pendidikan ekonomi. Vol: 4, No. 1.

Endi Sarwoko (2011). Kajian Empiris Entrepreneur intantion mahasiswa. Jurnal Ekonomi Bisnis. TH 16, No 2, Juli 2011.

Friedman, M. Marilyn.( 1998). Keperawatan Keluarga : Teori dan Praktik. Jakarta : EGC.

Indarti, Nurul dan Rokhima Rostiani. (2008). Intensi Kewirausahaan Mahasiswa: Studi Perbandingan Antara Indonesia, Jepang dan Norwegia. Jurnal ekonomika dan bisnis indonesia, Vol. 23, No. 4.

Ismail, Mohammad, Dkk (2009). entrepreneurial intention among Malaysian undergraduetes. Journal of business and management. Vol. 4 No 10 oktober.

Katz dan Gartner (1988). Properties of emerging organizations. Academy of management review 13 (3): 429-441.

Kautonan, Teemu (2008), intrepreneurial intentions in the third age: the impact of career history. Journal of management.

Kristianten, Stein \& Nurul. I (2003), determinants of entrepreneurial intention: the case of norwegian students. International journal of busines gadjah mada. Vol 5 No.1 Januari

Lestari, Raden. G, dan Rendra. W. The influence of attitude and contextual factor to the ability of entrepreneurship in school of economics dharma putra pekanbaru. Universitas Riau

Myers, David G. (2012). Psikologi sosial: social psychology.Jakarta: Salemba Humanika 
Nashori. (2007). Pelatihan Adversity Intellegence untuk Meningkatkan Kebermaknaan Hidup Remaja Panti Asuhan. Jurnal Psikologi No.23 Thn XII Januari 2007

Nursito, Sarwono dan Arif Julianto Sri Nugroho (2013). Analisis Pengaruh Interaksi Pengetahuan Kewirausahaan Dan Efikasi Diri Terhadap Intensi Kewirausahaan. Jurnal Bisnis. Vol. 5, No. 2.

Nursito, Sarwono dan Arif Julianto Sri Nugroho (2013). Analisis Pengaruh Interaksi Pengetahuan Kewirausahaan Dan Efikasi Diri Terhadap Intensi Kewirausahaan. Jurnal Bisnis. Vol. 5, No. 2.

Paulina, Irine, dan Wardoyo. (2012). faktor pendukung terhadap intensi berwirausaha pada mahasiswa. JDM. Vol 3, No. 1, pp:1-10.

Riyanti, B.P.D. 2003. Kewirausahaan Dari Sudut Pandang Psikologi Kepribadian. Jakarta : PT. Grasindo

Rustiyaningsih, Sri (2013). Faktor-faktor yang mempengaruhi intensi kewirausahaan. Widya warta No. 02 Tahun XXXV II. ISSN 0854-1981.

Sarwoko, Endi.(2011). Kajian Empiris Entrepreneur Intention Mahasiswa. Jurnal Ekonomi Bisnis, TH. 16, No. 2.

Shohib, Muhamad. (2013). Adversity quotient dengan minat entrepreneurship. Jurnal Ilmiah Psikologi Terapan. Vol. 01, No. 1. ISSN 2301-8267

Siti Zulaikha Wulandari. Dkk (2013) Analysis the influence of adversity quotient networking and capital through the entrepreneurial intentions of Unsoud's student. Jurnal Ekonomi, Unsoud.

Soemanto, Wasty. 2008. Pendidikan Wiraswasta. Jakarta: PT Bumi Aksara.

Stoltz, Paul G. (2000). Adversity quotient (terjemah): mengubah hambatan menjadi peluang. Jakarta: Gramedia.

Sugiyono. (2013). Metode penelitian bisnis. Bandung : Alfabeta.

Sukanti, Dkk (2011). Peran ibu dalam menumbuhkan jiwa wirausaha anak. Yogyakarta

Sumarni. (2006). Pengaruh konsep diri, prestasi belajar, dan lingkungan keluarga terhadap minat berwirausaha pada siswa siswa Smk $N 2$ Semarang. Jurnal penelitian. Universitas Negeri Surakarta.

Vemmy, Ceacilia S. (2012). Faktor-faktor yang mempengaruhi Intensi berwirausaha siswa Smk. Vol 2, nomor 1, februari 2012, UNY.

Volintia, anita.W dan Endang M (2013). Pengaruh pengalaman pendidikan kewirausahaan dan ketrampilan kejuruan terhadap motivasi berwirausaha siswa. Jurnal pendidikan vokasi, Vol 3 No 2, 2013.

Wei Li. (2005) .Entrepreneurial Intention Among International Students: Testing a Model of Entrepreneurial Intention.

Wijaya, Tony. (2007). Hubungan Adversity Intelligence dengan Intensi Berwirausaha. Jurnal Manajemen dan Kewirausahaan.Vol.9 No.2 September:117 127.

Wulandari, Suci. $(N d)$. Pengaruh efikasi diri terhadap minat berwirausaha pada siswa kelas XII di SMK Negeri 1 Surabaya. Surabaya

Xue Fa Tong, David. Y.K, Liang Chen. L (2011). factors influencing entrepreneurrial intention among uniersity students. Journal of social sciences. Vol. 3, No. 1. 